\title{
Rétting á fremra liðhlaupi í öxl með Cunningham-aðferðinni
}

\author{
Porsteinn H. Guð̋undsson ${ }^{1}$ læknir, Hjalti Már Björnsson ${ }^{1,2}$ læknir.
}

\section{A G R I P}

Inngangur: I byrjun árs 2013 var læknum bráđamóttöku Landspítala kennd ný aðferð til réttingar á lið̌hlaupi í öxl - Cunningham-aðferðin. Byggir hún á peirri kenningu að höfuð upphandleggs haldist utan liðskálar vegna spennu í löngu sin tvíhöfðavöðva., ${ }^{1,2}$ Markmið rannsóknarinnar var að meta áhrif innleiðslu aðferðarinnar á árangur réttinga, fjölda tilrauna, dvalartíma á bráđadeild, fjölda slævinga og verkjalyfjagjöf.

Efniviður og aðferðir: Leitað var rafrænt að sjúklingum sem komu á bráðamóttöku og fengu greininguna liðhlaup í öxl og/eða meðferðarkóðann rétting liơhlaups í öxl fyrir árin 2012 og 2013. Skráður var aldur og kyn sjúklinga, inn- og útskriftartími, aðferðir við réttingu, verkja- og slævingarlyf gefin og hvort um var að ræða fyrsta liðhlaup. Beitt var lýsandi tölfræði og t-test eða chi-square notað til að reikna út p-gildi.
Niðurstöður: Á rannsóknartímabilinu var alls reynt að̃ rétta axlarliðhlaup i 190 tilfellum og tókst rétting í 95\% tilvika á bráđamóttöku. Hlutfall sjúklinga par sem Cunningham-aðferðinni var beitt hækkaði úr 1\% i 27\% á milli ára. Meðalfjöldi tilrauna var 1,15 fyrra árið og 1,38 seinna árið $(p=0,002)$. Hlutfall heppnaðra réttinga i fyrstu tilraun lækkaði úr $81,6 \%$ í $66 \%(p=0,016)$ en rétting tókst á bráđamóttöku i $93,1 \%$ og $97,1 \%$ tilfella $(\mathrm{p}=0,305)$. Meðferðartíminn var svipaður milli ára eða 226 og 219 mínútur $(p=0,839)$. Hlutfall slævinga lækkað̌i úr $85,1 \%$ í 73,8\% $(p=0,024)$ en notkun verkjalyfja var svipuð milli ára eđa $70,6 \%$ og $69,6 \%$ ( $p=0,843)$.

Ályktun: Innleiðsla Cunningham-aðferðarinnar við réttingu axlarliðhlaupa leiddi til marktækrar fækkunar á slævingum en hafoi engin áhrif á dvalartíma á bráđadeild eđa heildarhlutfall heppnaðra réttinga.

\section{Inngangur:}

Liðhlaup í öxl eru algengust stórra liðhlaupa eða um $60 \%{ }^{1}$ Flest peirra eru fremri axlarliðhlaup eða $95 \%$, en pau verða oft við áverka á efri útlim í fráfærslu, útsnúningi og réttu eins og við fall á útrétta hendi. ${ }^{1,2,3}$ Mörgum aðferðum hefur verið lýst til að rétta axlarliðhlaup. Í yfirlitsgrein frá 2005 er mælt með Milch, Kocher eða Cunningham sem fyrstu meðferð. ${ }^{1}$ Við réttingu axlarliðhlaupa er oft notast við slævandi lyf eða gjöf sterkra verkjalyfja til að fá fram vöðvaslökun og verkjastillingu. Rétting liðhlaupa í öxl án slævingar hefur áður verið reynd með mismunandi aðferðum. ${ }^{4,5}$ Einnig er hægt að gefa deyfingu í axlarliðinn en sýnt hefur verið fram á styttri meðferðartíma sjúklings á bráðamóttökunni og færri fylgikvilla miðað við slævingu og gjöf verkjalyfja í æð. 6,7,8

Árið 2003 birti Neil Cunningham bráđalæknir grein um nýja aðferð við réttingu axlarliðhlaupa, kennda við hann sjálfan. Aðferðin byggir á peirri kenningu að öxlin haldist í óeðlilegri stöðu eftir liðhlaup vegna kröftugs samdráttar í lengri sin tvíhöfðavöðvans. ${ }^{9}$ Við notkun aðferðarinnar er mikilvægt að fá sjúkling til að slaka á, pví er aðferðin útskýrð í upphafi og sjúklingur upplýstur um að hún ætti að vera sársaukalítil. Best er að láta sjúkling sitja á stól með stuðning við bak. Handleggnum er rólega komið fyrir

'Bráđamóttaka Landspítala Fossvogi. ${ }^{2}$ ææknadeild Háskóla Íslands.

Fyrirspurnum svarar Hjalti Már Björnsson hjaltimb@landspitali.is

https://doi.org/10.17992//bl.2017.09.150

Greinin barst blaðinu 14. maí 2017, sampykkt til birtingar 31. júlí 2017. að bol með olnboga í mikilli beygju og úlnlið í bakbeygðri stöðu. Læknir situr eða krýpur á móti sjúklingi og notar aðra hendina til að styðja við handlegg sjúklings. Pví næst notar læknirinn hina hendina til að beita nuddi á vöðva í herðum, öxl og upphandlegg án nokkurs átaks eða hreyfingar axlarinnar (mynd 1). Einnig er sjúklingur beðinn að lyfta öxlum upp og aftur til að færa herðablaðið aftur. Til pess að hægt sé að rétta liðhlaup með pessari aðferð er nauðsynlegt að sjúklingur sé vel vakandi og geti fylgt fyrirmælum. Par sem Cunningham-aðferðinni fylgir óveruleg hreyfing á öxl er oft hægt að beita aðferðinni án slævingar eða verkjalyfja.,10 Í byrjun árs 2013 fór af stað átak par sem lögð var áhersla á að kenna öllum læknum bráðamóttöku Landspítalans í Fossvogi Cunningham-aðferðina við réttingu liðhlaupa í öxl. Haldinn var fundur með læknum deildarinnar par sem pessi aðferð var kennd munnlega, sýnt var myndband af aðferðinni og fengu allir læknar deildarinnar myndbandið sent í tölvupósti. Farið var yfir aðferðina við kennslu deildarlækna. Lögð var áhersla á að reyna fyrst pessa aðferð við réttingu á axlarliðhlaupum ef ástand sjúklings leyfði.

Markmið rannsóknarinnar var að meta með afturskyggnum hætti áhrif breytts verklags við réttingu liðhlaupa í öxl.

\section{Efniviður og aðferðir:}

Leitað var í rafrænum sjúkraskrám bráđamóttöku Landspítala að fengnum leyfum Siðanefndar Landspítala og Persónuverndar. Um var að ræða einstaklinga sem fengu greininguna liðhlaup í öxl og/ eða meðferðarkóðann rétting liðhlaups í öxl fyrir árin 2012 og 2013. 
Tafla I. Samanburður á aldri, kynjahlutfalli og hlutfalli fyrsta liðhlaups milli ára.

\begin{tabular}{lcc}
\hline & $\mathbf{2 0 1 2}$ & $\mathbf{2 0 1 3}$ \\
\hline Meðalaldur & 45,3 & 42,3 \\
\hline Kyn, karl/kona & $66,7(\mathrm{n}=58) /$ & $60,2(\mathrm{n}=62) /$ \\
& $33,3 \%(\mathrm{n}=29)$ & $39,8 \%(\mathrm{n}=41)$ \\
\hline Hlutfall fyrsta liðhlaups & $52,9 \%(\mathrm{n}=46)$ & $53,4 \%(\mathrm{n}=55)$. \\
\hline
\end{tabular}

Inntökuskilmerki voru klínísk merki um fremra liðhlaup og/ eða staðfesting á fremra liðhlaupi með myndgreiningarrannsókn og aldur 18-89 ára.

Útilokunarskilmerki voru meðvitundarskertir sjúklingar og var pá miðað við Glasgow coma-skalann (GCS) undir 15. Einnig voru peir útilokaðir sem höfðu aftara liðhlaup í öxl eða voru í lið við komu á bráđamóttöku.

Úr rafrænum sjúkraskrám voru fengnar upplýsingar um aldur og kyn sjúklinga, tímasetningu inn- og útskriftar, fyrstu til fjórðu aðferð við réttingu, lyf gefin til verkjastillingar (undir húð, í vöðva eða í æð) og slævingar, niðurstöðu röntgenmyndar fyrir og eftir réttingu og einnig hvort um var að ræða fyrsta liðhlaup eða ekki.

Vinnsla gagna og tölfræðileg úrvinnsla var unnin í Microsoft Excel og SPSS. Beitt var lýsandi tölfræði og við samanburð hópanna tveggja var notast við t-test. Marktækni var miðuð við 5\% marktektarmörk $(p<0,05)$.

\section{Niðurstöður:}

Komur á bráđamóttöku vegna fremra liðhlaups í öxl voru 97 árið 2012 og 125 á árinu 2013. Teknir voru út peir sem voru í lið við komu á bráðamóttöku (6 komur fyrra árið og 20 seinna árið) og peir sem engar upplýsingar voru um í bráđasjúkraskrá eða læknabréfi (ein koma á hvoru ári). Auk pess voru teknar út prjár komur á fyrra árinu og ein á pví seinna en par var um að ræða einstakinga sem lögðust beint inn á bæklunardeild án pess að tilraun væri gerð til réttingar á bráđamóttöku. Voru pví eftir 87 komur árið 2012 og 103 komur árið eftir sem tölfræðileg úrvinnsla var miðuð við. Af peim tókst að koma 81 (93\%) í liðinn á bráðamóttöku árið 2012 en 100 (97\%) árið 2013.

Í töflu I sést að hóparnir eru sambærilegir með tilliti til aldurs, kynjahlutfalls og hlutfalls fyrsta liðhlaups. Upplýsingar um hvaða aðferð var notuð við réttingu vantaði í 55\% tilfella fyrra árið $(n=46)$ og 33\% tilfella seinna árið $(\mathrm{n}=34)$. Hlutfall Cunningham-aðferðarinnar við fyrstu tilraun réttingar hækkaði úr 1\% (n=1) í 27\% (n=28) á milli ára (mynd 2). Sé miðað við allar tilraunir á bráðamóttöku (tilraun eitt til fjögur) hækkaði hlutfall Cunningham-aðferðarinnar milli 2012 og 2013 úr 2\% í 21,3\%, aðrar aðferðir voru notaðar í $54,5 \%$ og 47,5\% tilrauna til réttingar og óskráð aðferð í 43,4\% og $31,2 \%$ tilrauna.

Meðferðartíminn var ekki skráður í einu tilfelli hvort árið og upplýsingar um notkun slævandi lyfja vantaði í premur tilfellum fyrra árið. Skráningu á gjöf verkjalyfja í æð/vöðva/undir húð vantaði í tveimur tilfellum fyrra árið en einu tilfelli seinna árið. Tafla II sýnir að meðalfjöldi tilrauna jókst marktækt milli ára úr 1,15 í
Tafla II. Samanburður á meðferðartíma, meðalfjölda tilrauna, hlutfalli árangursrikrar réttingar í fyrstu tilraun og í heild.

\begin{tabular}{lccc}
\hline & $\mathbf{2 0 1 2}$ & $\mathbf{2 0 1 3}$ & Marktæki \\
\hline Fjöldi sjúklinga & 87 & 103 & \\
\hline Meðferðartími (mín) & 226 & 219 & $\mathrm{p}=0,839$ \\
\hline Meðalfjöldi tilrauna & 1,15 & 1,38 & $\mathrm{p}=0,002$ \\
\hline Fyrsta rétting heppnaðist & $81,6 \%(\mathrm{n}=71)$ & $66 \%(\mathrm{n}=68)$ & $\mathrm{p}=0,016$ \\
\hline $\begin{array}{l}\text { Rétting tókst á } \\
\text { bráðamóttöku }\end{array}$ & $93,1 \%(\mathrm{n}=81)$ & $97,1 \%(\mathrm{n}=100)$ & $\mathrm{p}=0,305$ \\
\hline
\end{tabular}

1,38 tilraun á sjúkling ( $\mathrm{p}<0,05)$ án pess að marktæk breyting yrði á meðferðartíma á bráðamóttöku. Tafla II sýnir einnig að marktækt fleiri réttingar heppnuðust í fyrstu tilraun fyrra árið en í heild tókst rétting á bráđamóttöku oftar seinna árið, en sá munur reyndist ekki marktækur.

Í pau 47 skipti sem skráð var hvaða aðferð var notuð árið 2012 heppnaðist rétting í 40 skipti, 1 með Cunningham-aðferð og 39 með öðrum aðferðum. Pví var hlutfall vel heppnaðra réttinga í fyrstu tilraun með ópekktri aðferð 31/40. Í pau 70 skipti sem skráð var hvaða aðferð var notuð árið 2013 heppnaðist rétting í 44 skipti, 8/28 með Cunningham-aðferð og 35/41 með öðrum aðferðum. Pví var hlutfall vel heppnaðra réttinga með ópekktri aðferð 24/34.

Tafla III sýnir samanburð milli ára á hlutfalli slævinga, verkjalyfjagjafa (undir húð/í vöðva/í æð) í heild. Par sést fækkun í notkun slævingar og reyndist sá munur marktækur milli ára. Ekki reyndist marktækur munur á notkun verkjalyfja (undir húð/í vöðva/í æð) milli ára.

Fyrra árið komu fram fimm beinbrot á röntgenmynd eftir réttingu sem ekki voru til staðar fyrir réttingu, tvö Bankartbrot, tvisvar merki um dæld í stærri beinhnjóti og einn HillSachs áverki. Í einu tilfelli til viðbótar sást Bankart-brot en engin röntgenmynd tekin fyrir réttingu. Seinna árið sáust prjú ný beinbrot eftir réttingu, par af tveir Hill-Sachs áverkar. Í fimm tilfellum til viðbótar sáust brot (tvö Bankart-brot, tveir Hill-Sachs áverkar og einu sinni merki um dæld í stærri beinhnjóti) en engin samanburðarmynd var tekin fyrir réttingu.

\section{Umræður:}

Liðhlaup í öxl er algengt bráðavandamál sem oft kemur upp fjarri heilbrigðisstofnunum. Pví getur purft langan og kostnaðarsaman sjúkraflutning til að koma lið í réttar skorður með hefðbundum aðferðum og slævingu. Í pessari rannsókn er metið hvort innleiðsla nýrrar aðferðar við réttingu liðhlaups í öxl geti auðveldað réttingu pannig að síður purfi að beita sérhæfðari aðferðum og slævingu sem ekki er á færi allra lækna.

Uppbygging rannsóknarinnar ber ekki Cunningham-aðferðina saman við aðrar aðferðir til réttingar. Hún gefur hins vegar vísbendingar um hvaða áhrif innleiðsla hennar hefur á meðferðartíma, fjölda slævinga og notkun sterkra verkjalyfja.

Notkun Cunningham-aðferðarinnar við fyrstu tilraun til réttingar jókst úr 1\% í 27\% eftir að læknum bráðamóttöku var kennd aðferðin. Fjöldi tilrauna til réttingar jókst en pað kemur ekki á óvart par sem læknum var í raun ráđlagt að reyna ávallt að nota Cunningham-aðferðina fyrst, áður en farið var í hefðbundnar að- 


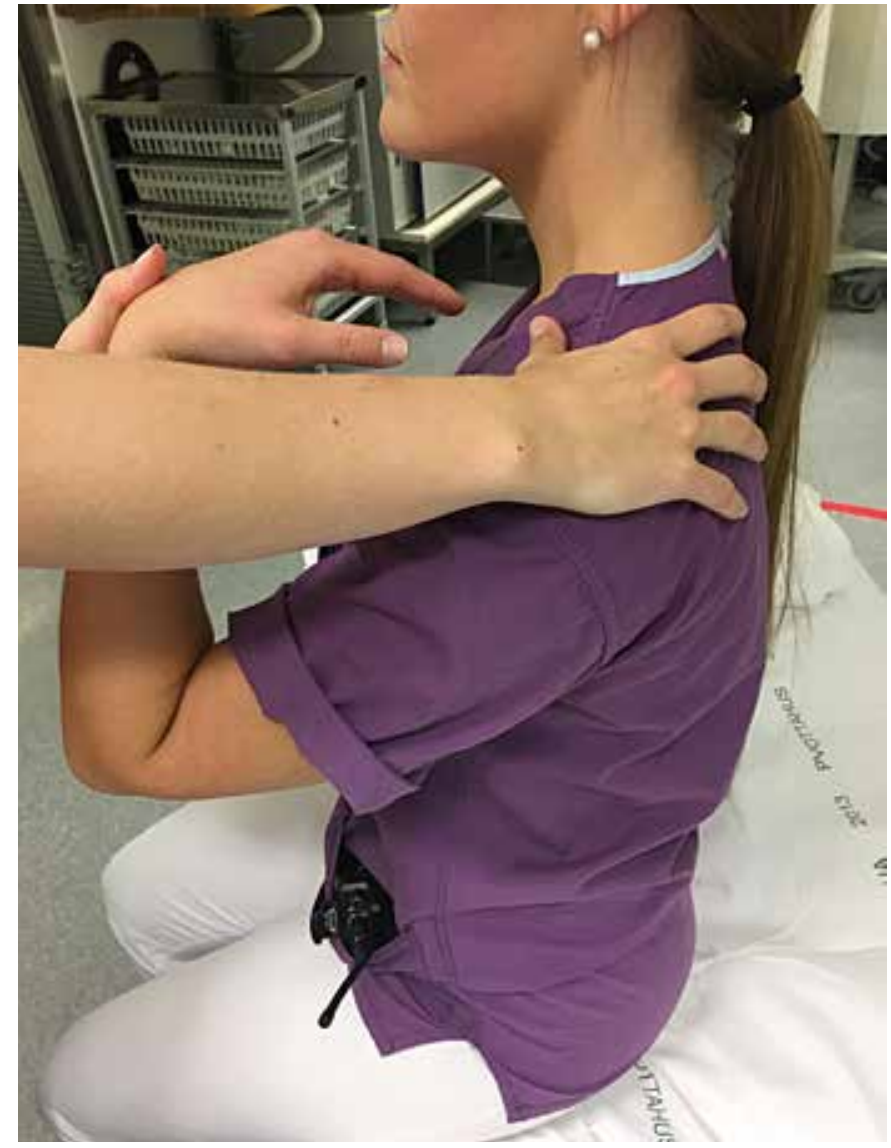

Mynd 1. Staða sjúklings við réttingu á liðhlaupi i öxl með Cunningham-aðferðinni.

ferðir til réttingar liðhlaupsins. Að reyna Cunningham-aðferðina tekur ekki langan tíma, eins og staðfestist af niðurstöðum rannsóknarinnar par sem ekki varð marktæk breyting á meðferðartíma milli ára. Einnig fækkaði slævingum marktækt eftir innleiðslu aðferðarinnar en ekki varð marktæk breyting á notkun verkjalyfja undir húð/í vöðva/í æð.

Cunningham-aðferðinni fylgir hverfandi hreyfing á öxl eða verkir fyrir sjúkling. Pví má reyna hana til réttingar liðhlaups áður en farið er í slævingu og aðrar tilraunir til réttingar sem líklegt er að fylgi meiri átök og valdi sjúklingi verkjum.

Höfundum er ekki kunnugt um rannsóknir par sem áhrif pess að ráðleggja Cunningham sem fyrstu aðferð eru metin hvað varð-

\section{Aðferðir við fyrstu réttingu}

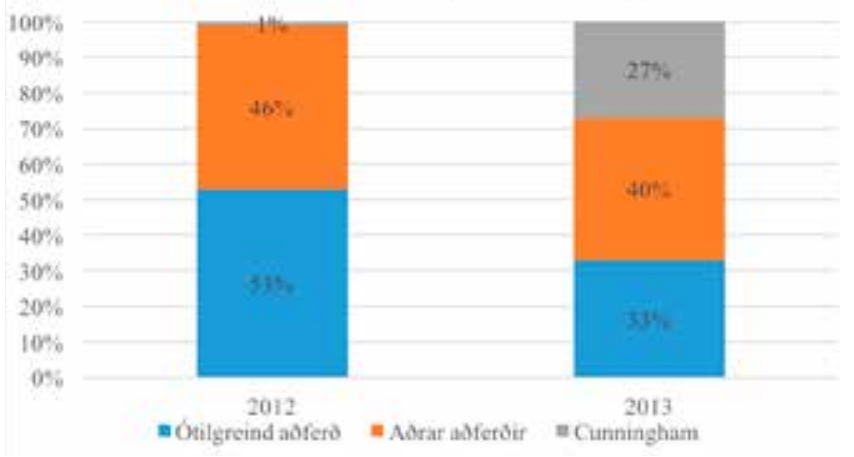

Mynd 2. Samanburður á aðferðum við fyrstu réttingu milli ára.
Tafla III. Samanburður á hlutfalli slævinga og hlutfalli verkjalyfja (undir húð/i vöđva/í æð) gefin við réttingu á bráđamóttöku.

\begin{tabular}{lccl}
\hline & $\mathbf{2 0 1 2}$ & $\mathbf{2 0 1 3}$ & Marktæki \\
\hline Fjöldi sjúklinga & 87 & 103 & \\
\hline Hlutfall slævinga & $85,1 \%(n=74)$ & $73,8 \%(n=76)$ & $p=0,024$ \\
\hline Verkjalyf gefin & $70,6 \%(n=60)$ & $69,6 \%(n=71)$ & $p=0,843$ \\
\hline
\end{tabular}

ar réttingarhlutfall, fylgikvilla eða meðferðartíma. Árið 2003 birti Neil Cunningham grein um fimm tilfelli par sem hann notaðist við Cunningham-aðferðina til réttingar á liðhlaupi í öxl. Rétting heppnaðist í fyrstu tilraun og meðferðartíminn var undir 80 mínútum í öllum tilfellunum. Fjórir höfðu áður purft slævingu til réttingar á axlarliðhlaupi en engin slæving var notuð í pessum fimm tilfellum. Einn fékk morfín í æð í sjúkrabíl fyrir komu en enginn fékk verkjalyf eftir komu á bráðamóttöku. ${ }^{9}$ Aðrir hafa birt tilfelli um aðferðina og árið 2011 var fjallað um 3 tilfelli par sem notast var við pessa aðferð. Rétting heppnaðist í fyrstu tilraun en tveir af premur fengu deyfingu í axlarliðinn fyrir réttingu vegna verkja. Tveir af premur fengu Bankart-brot á herðarblaðsskál sem ekki var til staðar á röntgenmyndum fyrir réttingu. ${ }^{10}$

Okkar gögn sýna ekki fram á að beiting Cunningham-aðferðarinnar einnar og sér hafi valdið beinbroti en frekari upplýsingar vantar til að útiloka að svo hafi verið. Erfitt er að draga ályktun um hlutfall nýrra brota par sem röntgenmynd af liðnum er ekki til staðar í öllum tilfellum fyrir réttingu og sjúklingar fáir. Til stóð að bera saman fjölda tilfella par sem beitt var djúpri slævingu og bera saman milli ára en skortur á upplýsingum, til dæmis um skammta slævingarlyfja sem gefin voru, gerði okkur pað ekki kleift. Pví var aðeins notast við upplýsingar um hvort slævingarlyf voru notuð eða ekki við fyrstu til fjórðu tilraun réttingar.

Á síðara árinu voru heldur fleiri sjúklingar komnir í lið aftur við komu á bráðamóttöku. Ferli peirra fyrir komu var ekki skoðað sérstaklega í pessari rannsókn en vitað er til pess að fleiri heilbrigðisstarfsmenn en læknar á bráđamóttöku voru farnir að pekkja til Cunningham-aðferðarinnar og vitað er um dæmi par sem henni var beitt af heilbrigðisstarfsmanni fyrir komu. Pví er hugsanlegt að innleiðsla aðferðarinnar hafi einnig fjölgað peim tilvikum par sem sjúklingur er kominn í lið fyrir komu á sjúkrahús.

Helstu annmarkar rannsóknarinnar er að skráningu á pví hvaða aðferð var notuð til réttingar liðhlaups var ábótavant par sem á fyrra árinu vantaði skráningu hjá meirihluta sjúklinga. Fræðsla um aðferðir til réttingar liðhlaups líkt og veitt var á bráðadeild Landspítala virðist hins vegar hafa skilað sér í pví að oftar var skráð hvaða aðferð var notuð, par sem petta hlutfall var komið niður í priðjung. Pá eru hvorki bornir saman verkir sjúklings við eða eftir inngripið né upplifun sjúklings meðan á pví stóð. Skýring pess er meðal annars sú að rannsóknin er afturskyggn og ekki voru til samhæfðar upplýsingar í sjúkraskrám pessara einstaklinga um verki sjúklings eða upplifun hans á fyrirfram ákveðnum skala.

Ekki er víst að kynningin á Cunningham-aðferðinni í lok árs 2012 hafi náð til allra lækna deildarinnar. Er pá miðað við ör skipti starfsfólks, sérstaklega kandídata og deildarlækna á deildinni sem sumir höfðu ef til vill ekki fengið formlega kennslu í framkvæmd og innleiðslu Cunningham-aðferðarinnar. Ekki er hægt að full- 
yrða hvort framkvæmd Cunningham-aðferðarinnar hafi verið rétt hjá læknum deildarinnar.

Samkvæmt reynslu lækna á bráðadeild Landspítala fylgja Cunningham-aðferðinni til réttingar á axlarliðhlaupi minni verkir og hreyfing á öxl en öðrum aðferðum. Í ljósi ofangreindra niðurstaðna mæla höfundar með að Cunningham-aðferðin sé reynd fyrst við axlarliðhlaup hjá samvinnupýðum sjúklingum án frábendinga. Með pví virðist vera hægt að fækka slævingum og hugsanlega ná sjúklingi fyrr í liðinn með minna átaki. Petta er ekki aðeins kostur á bráðamóttöku heldur einnig á heilsugæslustöðvum hér á landi utan stærri heilbrigðisstofnana par sem skort getur færni og aðstöðu til slævingar eða langt er í pá pjónustu.

\section{Pakkir:}

Við pökkum Ingibjörgu Richter fyrir að taka saman pýði rannsóknarinnar. Einnig fær Kristján Óli Jónsson deildarlæknir pakkir fyrir aðstoð við tölfræðiúrvinnslu.

\section{Heimildir}

1. Cunningham NJ. Techniques for reduction of anteroinferior shoulder dislocation. Emerg Med Australas. 2005 Oct-Dec;17(5-6):463-71.

2. Goss TP. Anterior glenohumeral instability. Orthopedics 1988;11:87-95

3. Cutts S., Prempeh M. \& Drew S. Anterior Shoulder Dislocation. Ann R Coll Surg Engl. Jan 2009; 91(1):2-7.

4. Garnavos C. Technical note: modifications and improvements of the Milch technique for the reduction of anterior dislocation of the shoulder without premedication. J. Trauma 1992:32:801-3.
5. Ceroni, Dimitri; Sadri, Hassan; Leuenberger, André, Anteroinferior Shoulder Dislocation: An Auto-Reduction Method Without Analgesia. Journal of Orthopaedic Trauma: August 1997;11:399-404.

6. Kuhn JE. Treating the initial anterior shoulder dislocation--an evidence-based medicine approach. Sports Med Arthrosc 2006;14:192.

7. Wakai A1, O'Sullivan $\mathrm{R}$ McCabe A. Intra-articular lignocaine versus intravenous analgesia with or without sedation for manual reduction of acute anterior shoulder dislocation in adults. Cochrane Database Syst Rev. 2011 Apr 13;(4).
8. Fitch RW1, Kuhn JE. Intraarticular lidocaine versus intravenous procedural sedation with narcotics and benzodiazepines for reduction of the dislocated shoulder: a systematic review. Acad Emerg Med. 2008 Aug;15(8):703-

9. Cunningham NJ. A new drug free technique for reducing

10. Harper H; Kang C, McGrane O, Walsh R. Too good to be true? Our experience with the Cunningham method of dislocated shoulder reduction. The American Journal of Emergency Medicine; 2012;30:376-377.

\section{ENGLISH SUMMARY}

\section{Reduction of shoulder dislocation with the Cunningham method}

Gudmundsson, Thorsteinn $\mathrm{H}^{1}$. Bjornsson, Hjalti Mar ${ }^{1,2}$

Introduction: The Cunningham technique has been shown to be an effective and simple method to reduce a dislocated shoulder. It is based on the theory that the humeral head remains outside the glenoid fossa due to tension in the long biceps tendon. In the beginning of 2013 doctors at the emergency department in Landspitali University Hospital (LUH) in Reykjavik were instructed in the Cunningham method for reduction of anterior dislocation without sedation. The goal of this retrospective study was to evaluate the impact of its induction with regards to number of attempts, successful relocations, sedation, use of analgesics and length of stay in the ED.

Material and methods: We searched our electronic database for patients coming to the ED in LUH in 2012 and 2013 with anterior shoulder dislocation. Information was obtained on age and gender, the ED length of stay, first to fourth attempted methods of reduction, medications given for pain relief and sedation and whether this was the first dislocation or not. We used descriptive statistics and comparing the two groups we used independent sample t-test or chi-square to calculate the $p$-value.
Results: During the study period, a reduction was attempted on 190 patients with a shoulder dislocation with $95 \%$ of dislocations successfully reduced in the ED. The proportion of patients on which the Cunningham method was applied on first attempt increased from 1\% to $27 \%$ between years. Average number of attempts was 1.15 in the first year and 1.38 the second year $(p=0.002)$. The proportion of successful first attempts fell from $81.6 \%$ to $66 \%(p=0.016)$ but successful relocation in the emergency department after all attempts was $93.1 \%$ and $97.1 \%$, respectively $(p=0,305)$. The duration of treatment was similar between years or 226 and 219 minutes $(p=0,839)$. Sedation ratio decreased from $85.1 \%$ to $73.8 \%(p=0.024)$ and use of analgesics was similar between years, $70.6 \%$ and $69.6 \%(p=0.843)$.

Conclusion: Induction of the Cunningham method resulted in a significant reduction in the need for sedation. It reduced the rate of successful relocations in the first attempt and increased the number of attempts to but had no effect on the length of stay in the emergency room or the overall rate of successful relocations.

'Department of Emergency, Landspitali - The National University Hospital, Reykjavik, Iceland. ${ }^{2}$ Faculty of Medicine, University of Iceland

Key words: Cunningham, shoulder, dislocation, reduction

Correspondence: Hjalti Már Björnsson hjaltimb@landspitali.is 